\title{
PEMBIAYAAN PERTANIAN DAN UPAYA MENINGKATKAN KESEJAHTERAN PETANI: ANALISA DATA MAKRO
}

\section{Feryanto}

Departemen Agribisnis, Fakultas Ekonomi dan Manajemen IPB

Email: fery.william@gmail.com

\begin{abstract}
ABSTRAK
Anggaran di sektor pertanian menunjukkan kenaikan yang relatif signifikan tahun 2004-2014, namun demikian peningkatan anggaran ini tidak diikuti dengan adanya perbaikan yang mendasar terhadap peningkatan kesejahteraan petani. Nilai Tukar Petani (NTP) sebagai indikator kesejahteraan petani menunjukkan bahwa kesejahteraan petani hanya berada pada kisaran 105. Oleh karena itu, penelitian ini bertujuan untuk menganalisis peranan dari pembiayaan di sektor pertanian terhadap kesejahteraan petani. Data yang digunakan ini adalah data sekunder periode tahun 2004-2014 (month to month) dan metode analisis menggunakan regresi berganda dengan pendekatan ordinary least square (OLS). Hasil penelitian ini menunjukkan bahwa pembiayaan pertanian memiliki peran untuk meningkatkan kesejahteraan petani, adapun komponen pembiayaan yang mempengaruhi kesejahteraan petani tersebut adalah kredit, subsidi pupuk, subsidi benih, dan PMA, sedangkan PMDN tidak berpengaruh signifikan.
\end{abstract}

Kata kunci: Pembiayaan Pertaian, Kesejahteran Petani, NTP

\begin{abstract}
Budget in the agricultural sector showed a significant relative increase in the period 2004-2014, however, the budget increase is not accompanied by an improvement in fundamental to improving the welfare of farmers. Term of trade of farmers (NTP) as an indicator of the welfare of farmers indicate that the welfare only in the range of 105. Therefore, the aimed of study to analyze the role of finance in the agricultural sector to the welfare of farmers. The data used are secondary data in the 2004-2014 periods (month to month), and analytical methods used are multiple regression with ordinary least square $(O L S)$ approach. The results of this study indicate that agricultural financing has a role to improve the welfare of farmers, while the financial component that affects the welfare of farmers is a credit, fertilizer subsidies, seed subsidies, and FDI, whereas no significant effect on domestic investment.
\end{abstract}

Keywords: Financing of Agriculture, Farmers Welfare, NTP 


\section{PENDAHULUAN}

Pembiayaan pertanian memegang peranan penting dalam mendukung peningkatan produksi, meningkatkan kesejahteran petani, dan pembangunan pertanian. Pembiayaan pertanian menjadi “pelumas' untuk menjalankan kegiatan pertanian pada level mikro dan makro. Berbagai program yang telah dijalankan oleh pemerintah sejak zaman orde baru, reformasi dan pasca reformasi untuk menciptakan isentif dan meningkatkan kesejateraan bagi petani. Menurut Kementerian Keuangan pada Tahun 2009-2014 anggaran pemerintah di sektor pertanian mengalami peningkatan. Tercatat pada tahun 2009 alokasi anggaran pemerintah yang dikeluarkan sebesar Rp. 49.7 trilliun, dan nilai ini mengalami peningkatan yang signifikan pada tahun 2014 menjadi Rp. 72.4 trilliun. Anggaran atau pembiayaan pertanian yang berasal dari pemerintah ini dialokasikan untuk Kementerian Pertanian, Irigasi (Kementerian PU), Subsidi (Pangan, Pupuk, dan Benih), Cadangan Beras Pemerintah, Stabilisasi Pangan, Benih Nasional, Cadangan Ketahanan Pangan dan transfer ke daerah pertanian.

Disamping itu pemerintah juga mendorong dunia perbankan untuk dapat meningkatkan jumlah dan akses pembiayaan ke sektor pertanian. Pada tahun 2009-2014 jumlah alokasi pinjaman yang disalurkan oleh perbankan ke sektor pertanian sebesar Rp. 77 394 Milyar pada tahun 2009 dan meningkat sebesar 185 persen pada tahun 2014 (Rp. 221 903 Milyar). Harapannya peningkatan ini akan memudahkan petani untuk melaksanakan kegiatan usahataninya, dengan demikian upaya untuk meningkatkan produksi dan kesejahteraan petani juga dapat dicapai. Hal ini sesuai dengan pandangan Ashari (2009), bahwa perbankan nasional memiliki potensi yang sangat besar untuk mendukung pembiayaan sektor pertanian, baik dari segi kemampuan menghimpun dan menyalurkan dana.

Selain dukungan pembiayaan yang berasal dari anggaran pemerintah dan perbankan nasional, investasi disektor pertanian juga sangat berperan dalam upaya meningkatkan kesejahteraan petani (Susilowati dan Kustari, 2009). Melalui kegiatan investasi, kegiatan perekonomian akan dapat bergerak dan memberikan multiplier effect bagi perekonomian di perdesaan maupun nasional.
Berdasarkan data dari Badan Koordinasi Penanaman Modal Republik Indonesia (BPKM RI) menunjukkan bahwa pada tahun 2014 (US\$ 2326.2 juta) terdapat peningkatan nilai penanaman modal asing (PMA) di sektor pertanian sebesar 179.1 persen sejak tahun 2010 (US\$ 833.4 juta). Dengan adanya investasi di sektor pertanian, diharapkan adanya pembangunan infrastruktur di sektor pertanian, adanya peningkatan usaha pengolahan dan produk yang berorientasi ekspor. Adanya peningkatan aktivitas ekonomi ini tentunya akan memberikan nilai tambah bagi produk pertanian. Sehingga dengan demikian, ada isentif yang diterima oleh petani baik dari segi kemudahan dan harga jual produk.

Data makro menunjukkan bahwa alokasi pembiayaan pertanian baik yang berasal dari pemerintah, perbankan dan swasta dalam bentuk investasi mengalami peningkatan setidaknya satu dekade terakhir. Adanya peningkatan pembiayaan di sektor pertanian diharapkan mampu meningkatkan kesejahteraan petani secara keseluruhan. Walaupun alokasi pembiayaan untuk sektor pertanian dari beberapa sumber mengalami peningkatan, namun kondisi secara umum yang dihadapi oleh pertanian dan petani tidak lebih baik. Berdasarkan hasil sensus pertanian (SP) yang dilakukan oleh BPS pada tahun 2013 tercatat bahwa masih rendahnya pendapatan petani yang diukur dari nilai tukar petani (NTP), menunjukkan bahwa NTP secara umum sepanjang tahun 2004-2014 berada pada kisaran $104-105$. Hal ini dapat dikatakan bahwa pendapatan yang diterima oleh petani dari kegiatan usahataninya sedikit lebih tinggi bila dibandingkan dengan pengeluaran konsumsinya. Sedangkan pertumbuhan NTP, rata-rata sebesar -0.097 persen sepanjang tahun 2004-2014.

Rendahnya tingkat pendapatan yang diterima petani memberikan implikasi kepada tingkat kemiskinan di pertanian dan perdesaan, tercatat bahwa pada tahun 2013 terdapat 28 juta penduduk miskin di perdesaan dan lebih dari 50 persen adalah penduduk yang bekerja di sektor pertanian (BPS, 2014), disamping itu juga sektor pertanian menampung setidaknya lebih dari 30 persen tenaga kerja. Hal ini diduga adanya penurunan tingkat kesejaheraan petani di perdesaan menyebabkan setidaknya lima juta rumah tangga petani beralih profesi dari sektor pertanian (buruh petani dan petani) 
ke profesi lain (Krisnamurthi dan Feryanto, 2015). Padahal beberapa kajian menunjukkan bahwa, peningkatan pembiayaan di sektor pertanian memiliki pengaruh terhadap peningkatan kesejateraan petani dan pengurangan kemiskinan di perdesaan (Bastin and Matteucci, 2007; Franks, 2009; Sayaka et al, 2010; Akudugu, 2014). Berdasarkan uraian tersebut, penelitian ini bertujuan untuk melihat bagaimana peranan pembiayaan di sektor pertanian terhadap kesejahteraan petani secara makro.

\section{METODE PENELITIAN}

Data. Data yang digunakan dalam penelitian ini merupakan data sekunder. Bentuk data berupa data time series dengan frekuensi data bulanan, dimana panjang data yang akan digunakan dalam penelitian ini adalah Januari 2004 (2004M1) sampai dengan Desember 2014 (2014M12), dengan pertimbangan untuk melihat pengaruh kebijakan peningkatan kesejahteraan petani dalam era pemerintahan yang sama. Sumber data diperoleh dari BPS, Bank Indonesia (BI), PUSDATIN Kementerian Pertanian, Kementerian Keuangan dan BKPM RI.

Frekuensi data yang digunakan dalam penelitian ini antar variabel memiliki frekuensi yang berbeda, seperti data subsidi pupuk dan benih tersedia dalam tahunan, sedangkan data kredit dalam bulanan dan investasi (PMA dan PMDN) dalam data kuartalan. Sehingga jika menggunakan data tahunan akan menyebabkan derajat bebas pada model menjadi sangat kecil, dengan periode hanya 11 tahun (2004-2014), sehingga digunakan data bulanan dengan melakukan interpolasi pada data subsidi dan investasi dengan menggnakan cubic spline dan log linear (Insukindro, 2011).

Metode Analisis. Metode analisis yang akan digunakan untuk melihat hubungan variabel tersebut adalah model regresi berganda. Menurut Gujarati dan Porter (2012), regresi berganda merupakan bentuk linear dari variabel-variabel tertentu dan komponen sisaan error. Sehingga jika hanya ingin melihat pengaruh variabel independen terhadap variabel dependen cukup dengan sederhana menggunakan model regresi berganda. Model regresi yang digunakan adalah regresi berganda dengan model logaritma natural atau double log, serta parameter regresi diduga dengan metode pendugaan OLS (Ordinary Least Square).
Adapun sifat-sifat OLS menurut Gujarati dan Porter (2012); penaksiran OLS tidak bias, penaksiran OLS mempunyai varian yang minimum, konsisten, efisien dan linier.

Metode double log dengan metode pendugaan OLS, dimaksudkan untuk melihat model pendugaan secara statistik. Interprestasi hasil dari model double log yakni hasil yang diperoleh menunjukkan elastisitas. Adapun model double log dari pendugaan peran pembiayaan terhadap peningkatan kesejahteraan petani, dapat dilihat pada Persamaan (1) berikut;

${\mathrm{Ln} \_n t \mathrm{t}_{\mathrm{t}}=\beta_{0}+\beta_{1} \ln \_ \text {kredit }_{t}+\beta_{2} \text { ln_pupuk }}_{t}+$

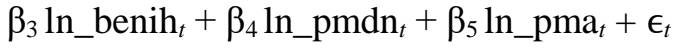

hipotesis: $\beta_{1}, \beta_{2}, \beta_{3}, \beta_{4}$, dan $\beta_{5}>0$.

Dimana;

$\mathrm{NTP}_{\mathrm{t}}=$ nilai tukar petani pada periode ke-t

Kredit $_{\mathrm{t}}=$ Alokasi kredit dari perbankan pada periode ke-t

Pupuk $_{\mathrm{t}}=$ Jumlah subsidi pupuk pada periode ke-t

Benih $_{\mathrm{t}}=$ Jumlah subsidi benih pada periode ke-t

$\mathrm{PMDN}_{\mathrm{t}}=$ Jumlah Investasi pertanian dari dalam negeri pada periode ke- $t$

$\mathrm{PMA}_{\mathrm{t}}=$ Jumlah Investasi pertanian dari luar negeri pada periode ke-t

Menurut Gujarati dan Porter (2012), kebaikan model dapat dilakukan dengan uji diagnostik ekonometrika, untuk mengidentifikasi apakah hasil estimasi sudah terbebas dari permasalahan yang berkaitan dengan asumsi klasik BLUE (Best, Linear, Unbiased, Estimator). Software yang akan digunakan adalah STATA versi 11, sehingga untuk melakukan uji dagnostik ekonometrika dilakukan dengan menggunakan uji Szroeter untuk melihat heteroskedastisitas, normalitas (uji normalitas Shapiro-Franci), dan uji multikolinearitas (uji Shapiro-Wilk).

Sebelumnya untuk melihat data yang diperoleh telah memiliki konstruk yang baik, maka akan dilakukan uji Conbrach Alpha (Latan, 2014). Dengan dipenuhinya asumsi-asumsi di atas, maka koefisien regresi yang diperoleh merupakan pendugaan linier terbaik yang tidak bias. Berdasarkan uji diagnostik yang dilakukan dapat disimpulkan bahwa tidak terdapat masalah pada data dan model yang dapat melanggar asumsi klasik 


\section{HASIL DAN PEMBAHASAN}

Teori dan hasil kajian empiris di negara lain menunjukkan bahwa pembiayaan pertanian memiliki peran dan pengaruh terhadap peningkatan kesejahteraan petani. Model peran pembiayaan pertanian terhadap kesejahteraan petani berdasarkan hasil estimasi pada Tabel 1, dapat dituliskan pada Persamaan 2.

$$
\begin{gathered}
\mathrm{Ln} \_n \mathrm{nt}_{\mathrm{t}}=4.953+\mathbf{0 . 0 3 7} \ln \_\mathrm{kredit}_{t}+\mathbf{0 . 0 6 6} \\
\operatorname{ln\_ pupuk}+\mathbf{0 . 0 1 4} \ln \_ \text {benih } \\
\mathbf{0 . 0 0 3} \ln \_ \text {pmdn } \\
+
\end{gathered}
$$

Berdasarkan hasil estimasi yang disajikan pada Tabel 1, dapat dijelaskan bahwa dalam estimasi yang dilakukan semua variabel menunjukkan kesesuaian arah yang konsisten dengan hipotesis dan teori $\left(\beta_{1}, \beta_{2}, \beta_{3}, \beta_{4}\right.$, dan $\beta_{5}$ $>0)$. Selain variabel investasi yang berasal dari dalam negeri (PMDN), semua variabel bebas yang digunakan berpengaruh signifikan dan nyata secara statistik terhadap kesejahteraan petani di Indonesia.

Tabel 1.

Hasil Estimasi Peran Pembiayaan Pertanian Dalam Upaya Meningkatkan Kesejahteraan Petani

\begin{tabular}{lll}
\hline Variabel & Koefisien & Prob \\
\hline Konstanta & 4.953 & $0.000^{*}$ \\
ln_kredit & 0.037 & $0.017^{* *}$ \\
ln_pupuk & 0.066 & $0.000^{*}$ \\
ln_benih & 0.014 & $0.020^{* *}$ \\
ln_pmdn & 0.003 & 0.574 \\
ln_pma & 0.008 & $0.015^{* *}$ \\
\hline R-Square & 0.6082 & \\
F-hit & 38.80 & \\
Prob > F & 0.000 & \\
Obs & 132 & \\
Keterangan: & & \\
*Signifikan pada tingkat 1 persen. \\
**Signifikan pada tingkat 5 persen.
\end{tabular}

Variabel kredit berpengaruh secara positif dan siginifikan secara statistik pada tingkat kepercayaan 95 persen (signifikansi $0.017<0.05)$. Hal ini menunjukkan bahwa peningkatan akses dan alokasi kredit komersial dari perbankan ke sektor pertanian memberikan implikasi kepada peningkatan tingkat pendapatan petani. Berdasarkan hasil empiris diperoleh bahwa peningkatan alokasi kredit bank komersial ke sektor pertanian sebesar satu persen akan meningkatkan pendapatan petani (NTP) sebesar 0.037 persen, ceteris paribus. Hasil ini sesuai dengan hasil empiris yang dilakukan oleh Biswanger and Khandker (1995) di India, Mosley (2010) di Bolivia Rosmiasti (2012) di Indonesia. Dengan memperhatikan kondisi ini, maka otoritas moneter dan jasa keuangan perlu mempertimbangkan mengeluarkan kebijakan untuk memberi kemudahan kepada petani dan pengusaha pertanian untuk mampu mengakses permodalan dengan mudah dan cepat. Otoritas moneter dalam hal ini Bank Indonesia, sebaiknya memperhatikan tingkat suku bunga kredit yang masih tinggi dan memberatkan petani. Keterbatasan dalam hal pemenuhan modal, terutama dalam bentuk kredit akan memaksa petani tetap dalam skala usaha yang tidak efisien. Karena petani tidak mampu melakukan ekspansi dan peningkatan skala usaha taninya. Saat ini tercatat suku bunga pinjaman kredit untuk kredit produktif di kisaran 12-16 persen per tahun. Suku bunga pinjaman ini masih jahu lebih tinggi bila dibandingkan dengan negara-negara tetangga di ASEAN yang rata-rata hanya satu digit (3-6 persen per tahun). Disamping itu kemudahan dalam hal persyaratan pengajuan kredit juga harus direformasi, karena prosedur dan persyaratan selama ini dinilai memberatkan. Serta pemerintah sebaiknya juga perlu memperhatikan untuk mengeluarkan skema kebijakan pemberian subsidi bunga kredit kepada petani. Karena perbankan menganggap sektor pertanian sebagai sektor yang penuh dengan risiko tinggi.

Subsidi pupuk adalah salah satu mekanisme transfer yang diberikan oleh pemerintah kepada para petani dengan memanfaatkan dana APBN. Teori dan kajian empiris menunjukkan bahwa subsidi pupuk mampu memberikan pengaruh positif terhadap peningkatan produksi hasil pertanian dan pendapatan petani, walaupun ada perdebatan bahwa subsidi pupuk juga memberikan dampak negatif (Herman et al, 2005; Syafa'at et al, 2006; dan World Bank, 2009). Namun demikian, dalam penelitian ini menunjukkan bahwa subsidi pupuk berpengaruh secara positif dan siginifikan secara statistik terhadap kesejahteraan petani di Indonesia selama periode 2004-2014 pada tingkat kepercayaan 99 persen (signifikansi $0.000<0.01$ ). Hal ini menunjukkan bahwa subsidi pupuk sangat 
berperan dalam upaya membantu petani untuk dapat melakukan kegiatan usahataninya.

Subsidi pupuk, berarti petani mendapat pupuk dengan harga yang lebih murah darih harga pasar, maka nilai yang dibayarkan petani untuk kegiatan produksi akan lebih rendah. Jika nilai yang dibayarkan petani lebih rendah dari yang diterima maka ada peningkatan terhadap nilai tukar petani. Peningkatan nilai tukar petani menunjukkan adanya perbaikan dalam hal pendapatan dan kesejahteraan petani. Hasil estimasi menunjukkan, jika pemerintah meningkatan subsidi pupuk sebesar satu persen maka akan meningkatkan penda-patan petani (NTP) sebesar 0.066 persen, ceteris paribus. Subsidi pupuk dalam pene-litian ini memberikan pengaruh paling besar terhadap peningkatan pendapatan petani bila dibandingkan dengan variabel-variabel lain.

Selain subsidi pupuk, pemerintah juga memberikan subsidi benih kepada petani. Kebijakan subsidi benih dicanangkan pemerintah mulai tahun 2004, saat itu untuk mendukung Program Peningkatan Produksi Beras Nasional (P2BN) dan revitalisasi pertanian 2005. Sama halnya dengan subsidi pupuk, subsidi benih secara teori juga akan memberikan dampak positif terhadap peningkatan produksi dan pendapatan petani. Karena petani mendapat benih yang terjamin kualitasnya dengan harga murah, sehingga petani diharapkan bisa efisen menjalankan kegiatan usahataninya. Berdasarkan hasil estimasi menunjukkan bahwa subsidi pupuk berpengaruh positif dan signifikan mempengaruhi tingkat pendapatan petani, pada tingkat kepercayaan 95 persen (signifikansi $0.020<0.05$ ). Interpretasi yang bisa diambil dari nilai koefisien sebesar 0.014 adalah apabila pemerintah meningkatkan alokasi pembiayaan pertanian dalam bentuk subsidi benih sebesar satu persen, maka tingkat pendapatan petani yang diukur dari NTP akan meningkat sebesar 0.014 persen, ceteris paribus. Namun demikian, perlu menjadi perhatian pemerintah jika subsidi benih mampu meningkatkan pendapatan petani, maka berdasarkan analisis tren adanya kecenderungan penurunan alokasi subsidi benih pada tahun 2016 harus diantisipasi.

Hasil estimasi pada variabel investasi yang berasal dari dalam negeri (PMDN) menunjukkan pengaruh yang postif, hal ini sesuai dengan teori yang ada bahwa investasi akan meningkatkan kapasitas produksi dan pendapatan. Namun demikian variabel PDMN secara statistik tidak siginifikan dan juga pengaruhnya juga sangat kecil sekali. Hal ini sesuai dengan temuan Herzer et al (2008), bahwa investasi asing memiliki dampak positif pada pertumbuhan ekonomi dan lebih produktif daripada investasi domestik. Hal ini juga menunjukkan bahwa, PMDN yang dialokasikan untuk sektor pertanian masih lebih kecil jumlahnya bila dibandingkan oleh sektor lain, serta sulitnya izin investai dan prosedur yang berbelit-belit bagi investor dalam negeri. Sehigga mereka lebih senang mengkonversi assetnya dalam bentuk valuta asing atau pasar modal.

Berbeda dengan PMDN, variabel PMA dari hasil estimasi menunjukkan bahwa PMA berpengaruh positif dan signifikan secara statistik mempengaruhi tingkat pendapatan petani, pada tingkat kepercayaan 95 persen (signifikansi $0.015<0.05$ ). Nilai koefisien dari variabel PMA sebesar 0.008 menunjukkan bahwa setiap kenaikan pembiayaan pertanian yang bersumber dari PMA sebesar satu persen akan meningkatkan tingkat pendapatan petani yang diukur dari NTP akan meningkat sebesar 0.008 persen, ceteris paribus. Jika dilihat dari besarnya pengaruh variabel lain yang signifikan, menunjukkan bahwa variabel PMA memiliki pengaruh yang lebih kecil. Hal ini menunjukkan bahwa pembiayaan pertanian yang berasal dari PMA tidak sepenuhnya dimanfaatkan dengan baik, serta dana yang diinvestasikan oleh asing ke Indonesia lebih banyak ke sektor lain, bukan pertanian. Masih terbatasnya infrastruktur dan sulitnya perizinan, birokrasi dan tingginya risiko di sektor pertanian menjadi pertimbangan investor asing untuk menginvestasikan dananya ke sektor pertanian.

\section{KESIMPULAN}

Secara umum tingkat kesejahteraan petani yang dilihat dari nilai tukar petani (NTP) dipengaruhi secara positif dan signifikan oleh variabel pembiayaan pertanian yang ditunjukkan oleh kredit pertanian, subsidi pupuk, subsidi benih, PMA. Subsidi pupuk merupakan variabel yang paling besar memberikan pengaruh pada kesejahteraan petani. Sedangkan variabel PMDN tidak signifikan memberikan pengaruh terhadap kesejahteraan petani.

Perlunya keberpihakan otoritas moneter, terutama dalam menurunkan tingkat suku bunga kredit terutama ke sektor produktif, 
seperti pertanian. Penurunan tingkat suku bunga ini akan menjadi pertimbangan perbankan untuk menjadi acuan menetapkan tingkat suku bunga. Disamping itu, Perbankan diharapkan juga mampu memberi kemudahaan dalam hal prosedur dan persyaratan, hendaknya stigma bahwa sektor pertanian sangat berisiko dikesampingkan. Pembiayaan dari anggaran pemerintah yakni APBN dalam bentuk subsidi, pelaksanaannya perlu diawasi terutama penylauran subsidi pupuk dan benih agar sampai ke kelompok sasaran yakni petani.

\section{UCAPAN TERIMAKASIH}

Terimakasih kepada Departemen Agribisnis FEM IPB yang telah memfasilitasi dan mendanai penelitian ini, dalam skema Penelitian Unggulan Departemen (PUD) Agribisnis FEM tahun 2015, dan kepada Herawati, M.Si yang membantu mencari dan mengumpulkan data dalam penelitian ini.

\section{DAFTAR PUSTAKA}

Akudugu, M. A. 2014. 'Estimating the effects of formal and informal credit on farm household welfare: a hierarchical comptetitive welfare model approach'. Journal of Development and Agricultural Economics, Vol 6 (10): 412-420.

Ashari. 2009. 'Peran perbankan nasional dalam pembiayaan sektor pertanian di Indonesia'. Forum Penelitian Agro Ekonomi, Vol 27 (1): 13-27.

Bastin, Anne and Nicola Matteucci. 2007. 'Financing coffee farmers in Ethiopia: Challenges and Opportunities'. Saving and Development, Vol 31 (3): 251-282.

Biswanger, Hans P., and Shahidur R. Khandker. 1995. 'The impact of formal finance on rural economy of India'. The Journal of Development Studies, Vol 3292): 232-262.

Franks, Jeremy. 2009.'Coping with credit crunch? A financial appraisal of UK farming'. Centre for Rural Economy Discussion Paper Series No. 25. Centre For Rural Economy-University of Newcastle Upon Tyne, United Kingdom.

Gujarati, Damodar N dan Dawn C. Porter. 2012. Dasar-dasar Ekonometrika. Raden Carlos Mangunsong [penerjemah]. Penerbit Erlangga. Jakarta.
Herzer, D., Klasen, S., and Nohwak-Lehman, F. 2008. "In search of FDI-led growth in developing countries: the way forward". Economic Modeling. 25(2008): 868878.

Herman, A.S., Djumarman, dan H. Sukesi. 2005. Kajian Sistem Distribusi Pupuk Bersubsidi. Laporan Penelitian. Badan Penelitian dan Pengembangan Perdagangan, Jakarta.

Insukindro. 2011. Permodelan Makroekonomi, Bahan Ajar, Pelatihan untuk dosen, mahasiswa S3 dan S2, diselenggarakan oleh FEB UGM, Yogyakarta, 29-30 September 2011.

Krisnamurthi, Bayu., dan Feryanto. 2015. 'Tantangan agribisnis masa depan' dalam Evolusi Pendidikan Tinggi Agribisnis Indonesia. Departemen Agribisnis FEM IPB.

Latan, Hengky. 2014. Aplikasi Analisis Data Statistik untuk Ilmu Sosial Sains dengan Stata. Penerbit Alfabeta. Bandung.

Mosley, P. 2010.'Microfinance and poverty in Bolivia'. The Journal of Development Studies, Vol 37 (4): 101-132.

Rosmiati, M. 2012. Perilaku Ekonomi Rumahtangga Pada Pasar Kredit Perdesaan. Disertasi. Program Pasca Sarjana Universitas Padjadjaran. Bandung.

Sayaka, Bambang et al. 2010. Peningkatan 20 Persen Akses Petani Terhadap Berbagai Sumber Pembiayaan Usahatani. Laporan Akhir. Pusat Sosial Ekonomi dan Kebijakan Pertanian-Kementerian Pertanian.

Susilowati, Sri Hery dan Reni Kustari. 2009. Strategi Penumbuhan dan Proteksi Sektor Pertanian. Makalah Seminar: Peningkatan Dayasaing Agribisnis Berorientasi Kesejahteraan Petani (14 Oktober 2009). Pusat Analisis Sosial Ekonomi dan Kebijakan Pertanian. Kementerian Pertanian. Bogor.

Syafa'at, N., A. Purwoto, M. Maulana, dan C. Muslim. 2006. Analisis Besaran Subsidi Pupuk dan Pola Distribusinya. Laporan Akhir Penelitian, Pusat Analisis Sosial Ekonomi dan Kebijakan Pertanian, Bogor.

World Bank. 2009. Fertilizer Subsidies in Indonesia, Policy Note. Indonesia Agriculture Public Expenditure Review, the World Bank, Jakarta. 